\title{
The Contribution of Hand Muscle Power And Wrist Flexibility To Jumping Smash Hit Skill of Badminton Extracurricular Students At Sman 06 Mukomuko Bengkulu
}

\section{Kontribusi Daya Ledak Otot Lengan Dan Kelentukan Pergelangan Tangan Terhadap Kemampuan Jumping Smash Siswa Ekstrakurikuler Bulutangkis Di Sman 06 Mukomuko Bengkulu}

\author{
Deffri Anggara1 , Bismi Fornandes 2 \\ 1,2 Departemen Phsycal Education Study Program, Universitas \\ Dehasen Bengkulu, Indonesia
}

Corresponding Author: :

deffri.anggara@unived.ac.id

fornandesbismi@gmail.com

\section{How to Cite :}

Anggara, D., Fornandes, B (2020). The Contribution of Hand Muscle Power and Wrist Flexibility to Jumping Smash Hit Skill og Badminton Extracurricular Students at SMAN 06 Mukomuko Bengkulu. Hanoman Journal: Phsycal Education and Sport, 1 (2). DOI: https://doi.org/10.37638/hanoman.1.2.72-77

ARTICLE HISTORY

Received [03 September 2021]

Revised [15 November 2021]

Accepted [20 Desember 2021]

Kata Kunci :

Daya Ledak Otot Lengan, Kelentukan Pergelangan Tangan, Kemampuan Jumping Smash Bulutangkis

Keywords :

Hand Muscle Power, Wrist Flexibility, Jumping Smash Hit Skill of Badminton
This is an open access article under the $\underline{C C-B Y-S A}$ license

\begin{abstract}
ABSTRAK
Tujuan dari penelitian ini adalah untuk mengetahui kontribusi kekuatan otot tangan dan kelenturan pergelangan tangan terhadap siswa Smash. Ini adalah penelitian korelasional. Populasi penelitian ini adalah seluruh siswa peserta ekstrakurikuler bulutangkis di SMAN 06 Mukomuko 25 siswa. Pengambilan sampel dilakukan dengan menggunakan metode total sampling yang menghasilkan 25 siswa laki-laki. Teknik pengumpulan data adalah: 1) uji kekuatan tangan dengan one hand medicine ball put, 2) kelenturan pergelangan tangan diukur dengan menggunakan arc-ruler, 3) keterampilan jumping smash hit diuji dengan menggunakan lapangan bulu tangkis dengan grading box. Analisis data dilakukan dengan korelasi product moment dan korelasi ganda dengan signifikansi $a=0,05$. Hasil analisis data adalah: 1) Ada hubungan yang signifikan antara kekuatan otot tangan dengan keterampilan jumping smash hit siswa pada ekstrakurikuler bulutangkis di SMAN 06 Mukomuko, Bengkulu dengan kontribusinya sebesar 39,19\%, 2) Ada hubungan yang signifikan. antara kelenturan pergelangan tangan dengan ketrampilan jumping smash hit siswa dan kontribusinya sebesar $38,69 \%$, 3) Ada pengaruh yang signifikan antara kekuatan otot dan kelenturan pergelangan tangan terhadap keterampilan lompat smash hit siswa sebesar 55,65\%.
\end{abstract}

\section{ABSTRACT}

This is a correlational research. The population of this research is all

72 | Anggara, D., Fornandes, B (2020). The Contribution of Hand Muscle Power and Wrist Flexibility.... 
students participating in the badminton extracurricular at SMAN 06 Mukomuko 25 students. The sampling is done by using total sampling method which result in 25 male students. The data collection techniques are : 1) hand power is tested by one hand medicine ball put, 2) wrist flexibility is measured by using arc-ruler, 3) jumping smash hit skill is tested by using badminton court with grading boxes. The data is analysed by product moment correlation and dual correlation with $a=0.05$ significance. The result of the data analysis are: 1) There is a significant relation between hand muscle power and students jumping smash hit skill in badminton extracurricular class at SMAN 06 Mukomuko, Bengkulu and the contribution is $39,19 \%, 2)$ There is significant relation between wrist flexibility and the students jumping smash hit skill and the contribution is 38,69\%,

3) There is significant contribution of both muscle power and wrist flexibility to the students jumping smash hit skill as much as 55,65\%.

\section{PENDAHULUAN}

Mokomuko merupakan salah satu Kabupaten di Indonesia yang sangat peduli terhadap pembinaan olahraga bulutangkis, secara berkesinambungan dengan tujuan mendapatkan bibit berpotensi yang siap membawa nama daerah ke tingkat nasional maupun internasional. Pengembangan pembinaan olahraga ini dilaksanakan mulai dari pendidikan di Sekolah Dasar, Sekolah Menengah Pertama, Sekolah Menengah Atas, Perguruan Tinggi dan pada masyarakat. Pengembangan pembinaan olahraga di Sekolah dilaksanakan melalui kegiatan ekstrakurikuler.

SMA Negeri 06 Mukomuko Propinsi Bengkulu adalah salah satu sekolah yang melaksanakan kegiatan ekstrakurikuler dalam pembinaan cabang olahraga bulutangkis, dimana kegiatan ekstrakurikuler ini dilaksanakan diluar jam mata pelajaranan yaitu dengan tiga kali tatap muka perminggu yang jadwal latihannya sudah diprogramkan oleh pelatih. Ekstrakurikuler ini merupakan program sekolah, berupa kegiatan siswa yang bertujuan memperdalam dan memperluas pengetahuan siswa, optimalkan pelajaran yang terkait, menyalurkan bakat dan minat, kemampuan dan keterampilan serta untuk lebih memantapkan kepribadian siswa. Olahraga cabang bulutangkis cukup diminati siswa ekstrakurikuler bulutangkis di SMA Negeri 06 Mukmuko Propinsi Bengkulu.

Hasil tes awal kemampuan jumping smash yang penulis lakukan terhadap 25 orang siswa yang mengikuti ekstrakurikuler bulutangkis di SMA Negeri 06 Mukomuko Propinsi Bengkulu, dengan menggunakan Penilaian Acuan Patokan (PAP) skala 5 diperoleh, 2 (8\%) siswa yang memiliki kemampuan smash dalam katgori baik sekali, 3 orang (12\%) siswa kategori baik, 10 orang (40\%) siswa kategori sedang, 10 orang (40\%) siswa kategori kurang, dan kategori kurang sekali tidak ada.

Berdasarkan uraian di atas, maka pada kesempatan ini penulis ingin melakukan suatu penelitian untuk mendapatkan data dan informasi yang 
mendekati kebenaran ilmiah mengenai daya ledak otot lengan dan kelentukan pergelangan tangan sebagai faktor yang mempengaruhi kemampuan jumping smash siswa ekstrakurikuler Bulutangkis di SMA Negeri 06 Mukomuko Propinsi Bengkulu.

\section{METODE PENELITIAN}

Jenis penelitian ini adalah penelitian korelasional. Populasi dalam penelitian ini yaitu seluruh siswa yang mengikuti ekstrakurikuler bulutangkis di SMA Negeri 06 Mukomuko Privinsi Bengkulu yang berjumlah 25 orang. Teknik pengambilan sampel menggunakan total sampling. Dengan demikian sampel dalam penelitian ini berjumlah 25 orang siswa putra. Teknik pengambilan data yaitu : 1) Daya ledak otot lengan dites dengan one hand medicine ball put, 2) Kelentukan pergelangan tangan di ukur dengan menggunakan busur, 3) Kemampuan jumping smash dites menggunakan lapangan bulutangkis dengan kotak-kotak nilai yang telah tertera dalam lapangan. Data dianalisis dengan korelasi product moment dan korelasi ganda dengan taraf signifikan $\alpha=0.05$.

\section{HASIL}

Hasil analisis menunjukan bahwa daya ledak otot lengan $(X \neg 1 \neg)$, memiliki hubungan dengan kemampuan jumping smash siswa ekstrakurikuler bulutangkis di SMA Negeri 06 Mukomuko Propinsi Bengkulu. Hubungan daya ledak otot lengan dengan kemampuna jumpinng smash bernilai rhitung $0.626>$ rtab 0.396 . Berdasarkan uji t ternyata thitung 3.869> ttabel -1,714 dengan . Kontribusi daya ledak otot lengan terhadap kemampun jumping smash siswa ekstrakurikuler bulutangkis di SMA Negeri 06 Mukomuko Propinsi Bengkulu adalah sebesar $39.19 \%$.

Hasil analisis menunjukan bahwa kelentukan pergelangan tangan $(X \neg 2 \neg)$, memiliki hubungan terhadap kemampuan jumping smash pada siswa ekstrakurikuler bulutangkis di SMA Negeri 06 Mukomuko Propinsi Bengkulu. Hubungan kelentukan pergelangan tangan terhadap kemampuan jumping smash bernilai rhitung $0.622>$ rtab 0.396. Berdasarkan uji t ternyata thitung $3.810>$ ttabel $\neg 1,714$ dengan . Kontribusi kelentukan pergelangan tangan terhadap kemampuan jumping smash pada siswa ekstrakurikuler bulutangkis di SMA Negeri 06 Mukomuko Propinsi Bengkulu adalah sebesar 38.69\%..

Pengujian hipotesis ke tiga ini dilakukan menggunakan korelasi ganda. Berdasarkan hasil perhitungan korelasi ganda diperoleh rhitung $=0.746>$ rtabel 0.396. Berdasakan uji F ternyata Fhitung $=13,804>$ Ftabel 3.44. Kontribusi daya ledak otot lengan dan kelentukan pergelangan tangan, secara bersama-sama terhadap kemampuan jumping smash pada siswa ekstrakurikuler bulutangkis di SMA Negeri 06 Mukomuko Propinsi Bengkulu adalah sebesar 55.65\%. 


\section{PEMBAHASAN}

Kontribusi daya ledak otot lengan terhadap kemampuan jumping smash pada siswa ekstrakurikuler bulutangkis di SMA Negeri 06 Mukomuko Propinsi Bengkulu adalah sebesar 39.19\%. Artinya semakin daya ledak otot lengan seseorang maka semakin baik pula kemampuan jumping smashnya. Menurut Bompa dalam Syafruddin (2011:72-73) mendefinisikan, “Daya ledak sebagai produk dari dua kemampuan yaitu kekuatan (strength) dan kecepatan (speed) untuk melakukan force maksimum dalam waktu yang cepat". Menurut Annarino dalam Arsil (1999:71) daya ledak adalah "Kekuatan dan kecepatan kontraksi otot secara dinamis explosive dalam waktu yang cepat". Berdasarkan dari pendapat para ahli di atas maka dapat disimpulkan bahwa daya ledak otot lengan adalah kemampuan otot mengarahkan kekuatan dalam waktu yang sangat singkat untuk memberikan objek momentum yang paling baik pada tubuh atau objek dalam suatu gerakan explosive yang utuh mencapai tujuan yang dikehendaki.

Daya ledak otot lengan merupakan salah satu komponen dasar kondisi fisik yang sangat penting dalam olahraga bulutangkis, terutamak sekali saat melakukan smash, baik itu smash pendek maupun smash jauh. jika seorang pemain tidak memiliki daya ledak otot lengan yang bagus saat melakukan smash, tentunya shuttlecock yang dipukul tidak kuat dan mudah untuk dikembalikan oleh lawan. Smash dalam permainan bulutangkis merupakan pukulan bola (shutlecock) tajam ke bawah dengan kecepatan yang keras. Smash yang dimaksud dalam penelitian ini adalah smsah dilakukan dengan sekuat tenaga sehingga tidak bisa dikembalikan lawan. Dalam melakukan jumping smash sangat dibutuhkan kekuatan dan daya ledak otot lengan dan otot jari-jari tangan agar mampu memukul bola ke daerah lapangan lawan dengan cepat dan keras, yang berjarak 6 sampai 12 meter. Tentunya hal ini sangat berkaitan dengan kualitas otot yang dimiliki seseorang dan tidak dapat dipisahkan dengan fungsi utama dari jaringan otot. Fungsi utama dari jaringan otot yaitu: untuk menghasilkan gerakan lewat kemampuannya berkontraksi dan membangun ketegangan. Untuk melatih daya ledak otot lengan dapat dilakukan dengan melakukan latihan angkat beban yang sesuai dengan kemampauan otot kita. Kemampuan kondisi fisik, kekuatan dan daya ledak otot lengan merupakan salah satu aspek yang akan banyak mempengaruhi kemampuan jumping smash, artinya saat melakukan jumping smash yang didukung oleh kondisi fisik. Salah satunya daya ledak otot lengan. Dengan dimikian untuk mendapatkan daya ledak otot lengan yang baik tentunya diperlukan latihan-latihan yang dapat meningkatkan daya ledak otot lengan seperti latihan push-up dan latihan pull up (gantung angkat tubuh) dan melempar dan menangkap bola dengan bola medicine secara sendiri-sendiri dan berpasangan.

Kelentukan pergelangan tangan memberikan kontribusi sebesar $38.69 \%$ terhadap kemampuan jumping smash siswa. Menurut Hendri (2013:71) "Kelentukan yaitu kemungkinan gerak maksimal yang dapat dilakukan oleh suatu 
persendian". Seseorang dikatakan lentur apabila ia mampu membungkuk dengan maksimal (mampu mencium lututnya) mampu duduk dengan kedua kaki terbuka, atau mampu melentik dengan sempurna sehingga kepalanya mendekati tumit atau ia mampu meliukkan badannya ke kiri dan ke kanan secara maksimal. Dari penjelasan di atas, maka dapat dikemukakan bahwa kelentukan pergelangan tangan merupakan faktor penting yang dapat mempengaruhi kemampuan jumping smash pada siswa ekstrakurikuler bulutangkis di SMA Negeri 06 Mukomuko Propinsi Bengkulu.Sebab dengan pergelangan tangan yang lebih fleksibel maka gerakan yang dilakukan akan semakin luas maka dengan begitu pengaturan dan kotrol akan lebih mudah dilakukan termasuk yaitu keterampilan dalam memposisikan bola. Kelentukan merupakan kemampuan pergelangan/ persendian untuk dapat melakukan gerakan kesemua arah dengan amplitude gerakan yang besar dan luas sesuai dengan fungsi persendian yang digerakan. Dengan demikian, orang yang lentuk adalah orang yang mempunyai ruang gerak yang luas dalam sendi-sendinya serta mempunyai otot yang elastis.

Berdasarkan hasil penelitian di atas, jelaslah bahwa kelentukan pergelangan tangan memberikan kontribusi yang cukup besar terhadap kemampuan jumping smash pada siswa ekstrakurikuler bulutangkis di SMA Negeri 06 Mukomuko Propinsi Bengkulu. Artinya semakin baik kelentukan pergelangan tangan maka semakin baik pula kemampuan jumping smash siswa. Oleh karena itu perlu kiranya menjadi perhatian pelatih bulutangkis SMA Negeri 06 Mukomuko Propinsi Bengkulu untuk dapat meningkatkan lagi kelentukan pergelangan tangan atlet, diantaranya memberikan latihan memutar-mutar pergelangan tangan dengan menggunakan beban maupun tanpa beban. Berdasarkan hasil perhitungan korelasi ganda diperoleh rhitung $=0.746>$ rtabel 0.361 dan uji $\mathrm{F}$ ternyata Fhitung $=13,804>$ Ftabel 3.44. Dengan demikian dapat disimpulkan bahwa terdapat hubungan yang berarti (signifikan) antara daya ledak otot lengan dan kelentukan pergelangan tangan secara bersama-sama terhadap kemampuan jumping smash pada siswa ekstrakurikuler bulutangkis di SMA Negeri 06 Mukomuko Propinsi Bengkulu dan berkontribusi terhadap kemampuan jumping smash sebesar $=55,65 \%$.

Jumping smash adalah pukulan smash yang yang dilakukan sambil melompat tinggi yang dilakukan sekuat mungkin. Siswa yang memiliki daya ledak otot lengan baik tentu dapat melakukan jumping smash dengan keras, tajam dan mematikan sehingga lawan tidak bisa mengembalikannya. Artinya semakin baik daya ledak otot lengan dan kelentukan pergelangan tangan, maka sejalan dengan itu semakin baik pula kemampuan jumping smashnya. Kelentukan pergelangan tangan, akan dapat menimbulkan kemampuan untuk melakukan gerak sendi dari berbagai arah di dalam melakukan pukulan jumping smash, dimana tangan yang akan sangat berpengaruh dalam melecutkan secara horisontal suatu pukulan yang keras, tepat dan terarah pada sasaran yang diinginkan.

76 | Anggara, D., Fornandes, B (2020). The Contribution of Hand Muscle Power and Wrist Flexibility... 
Berdasarkan hasil penelitian di atas, jelas bahwa daya ledak otot lengan dan kelentukan pergelangan tangan memberikan kontribusi yang cukup besar terhadap kemampuan jumping smash pada siswa ekstrakurikuler bulutangkis di SMA Negeri 06 Mukomuko Propinsi Bengkulu. Oleh karena itu kedua faktor tersebut di atas perlu dilatih dan perlu diperhatikan baik dari pelatih maaupun dari siswa itu sendiri. Dengan demikian upaya yang dapat dilakukan untuk meningkatkan kemampuan jumping smash perlu ditingkatkan latihan daya ledak otot lengan dan kelentukan pergelangan tangan secara terprogram dan kontiniu.

\section{KESIMPULAN DAN SARAN}

Hasil penelitian dapat disimpulkan sebagai berikut :

Terdapat hubungan yang signifikan antara daya ledak otot lengan terhadap kemampuan jumping smash siswa ekstrakurikuler bulutangkis di SMA Negeri 06 Mukumuko Provinsi Bengkulu dengan rhitung $0.626>$ rtab 0.396 dan t hitung $=$ $3.849>$ t tabel 1.714 dengan kontribusi sebesar 39,19\%.Terdapat hubungan yang signifikan antara kelentukan pergelangan tangan terhadap kemampuan jumping smash siswa ekstrakurikuler bulutangkis di SMA Negeri 06 Mukomuko Provinsi Bengkulu dengan rhitung $0.622>$ rtabel 0.396 dan t hitung $=3.810>t$ tabel 1,714 dengan kontribusi sebesar 38,69\%.Terdapat hubungan yang signifikan antara daya ledak otot lengan dan kelentukan pergelangan secara bersama-sama terhadap kemampuan jumping smash siswa ekstrakurikuler bulutangkis di SMA Negeri 06 Mukomuko Provinsi Bengkulu dengan rhitung $=0.746>$ rtabel 0.361 dan Fhitung $=$ 13,804 > Ftabel 3.44 dengan kontribusi sebesar 55,65\%.

Berdasarkan kesimpulan di atas, maka disarankan kepada : Pelatih, diharapkan agar meningkatkan bentuk-bentuk latihan daya ledak otot lengan dan kelentukan pergelangan tangan sehingga dapat meningkatkan kemampuan jumping smash siswa. Siswa, diharapkan agar lebih rajin dan tekun melakukan latihan-latihan kondisi fisik seperti latihan daya ledak otot lengan dan kelentukan pergelangan, sehingga dapat meningkatkan kemampuan jumping smash.

\section{DAFTAR PUSTAKA}

1. Arsil, 1999. Pembinaan Kondisi Fisik. FIK Universitas Negeri Padang

2. Depdiknas. 2006. Pedoman Pelaksanaan Ekstrakurikuler. Jakarta : Depdiknas.

3. Hendri, Irawadi. 2013. Kondisi Fisik dan Pengukurannya. Padang : FIK UNP

4. Khairuddin. 2000. Pedoman Permainan Bulutangkis. Padang : FIK UNP

5. Riduwan. 2005. Belajar Mudah Penelitian untuk Guru-Karyawan dan Peneliti Pemula. Bandung : Alfabeta

6. Syafruddin, 2011. Ilmu Kepelatihan Olahraga. Padang: Fakultas IImu Keolahragaan Universitas Negeri Padang. 